\title{
Relation between serum group II pepsinogen concentration and the degree of Brunner's gland hyperplasia in patients with chronic renal failure
}

\author{
H PAIMELA, M HÄRKÖNEN, S-L KARONEN, L G TALLGREN, \\ S STENMAN, AND J AHONEN \\ From the Fourth Departments of Surgery and of Medicine, Departments of Clinical Chemistry and of \\ Pathology, Helsinki University Central Hospital, Helsinki, Finland
}

SUMmaRY Serum concentrations of group I and II pepsinogens (PG I and PG II) were determined in 15 patients with chronic renal failure. Gastroduodenoscopy with biopsy and acid secretion tests were also performed. Five patients had histologically confirmed severe Brunner's gland hyperplasia manifesting as multiple polyps in the duodenal bulb. Five patients had a mild form of Brunner's gland hyperplasia which was evident only by histological analysis. Five had no signs of such alterations. The three groups of patients were comparable in age, sex, mean level of serum creatinine, mean duration of dialysis treatment, distribution of non-dialysed and dialysed patients, and gastric histology. In patients with severe Brunner's gland hyperplasia the mean serum PG II concentration was significantly higher than in the other patients. Both the serum PG I and the serum PG II concentrations decreased after receiving a well functioning renal transplant in the two patients who underwent transplantation.

As we have shown earlier, about $15 \%$ of patients with chronic renal failure have hyperplastic Brunner's glands detected at endoscopy as multiple polyps in the duodenal bulb. ${ }^{1}$ Similar observations have been reported by others. ${ }^{2-4}$ Brunner's glands are known to be involved in the mucous and pepsin secretion. $^{56}$ Samloff and Liebman have shown histochemically that it is the group II of the pepsinogens, which originates in these glands. ${ }^{7}$ As noted by Samloff in his extensive review, ${ }^{8}$ the group II pepsinogens (PG II) are not normally excreted into the urine while the group I pepsinogens (PG I) are known to be excreted.

In the present study the level of PG II was investigated in relation to the degree of Brunner's gland hyperplasia in renal failure. This was done by determining the serum PG I and II levels and the gastric acid secretion capacity in uraemic patients with different degrees of Brunner's gland hyperplasia.

Address for correspondence: H Paimela MD. Fourth Department of Surgery, Helsinki University Central Hospital, Kasarmikatu 11-13, SF-00130 Helsinki 13. Finland

Received for publication 4 May 1984

\section{Methods}

PATIENTS

The series consisted of 15 patients (six women and nine men; mean age $47 \cdot 8$ years, range $29-68$ years) with a mean concentration of serum creatinine 734.0 $\mu \mathrm{mol} / 1(83.0 \mathrm{mg} / 100 \mathrm{ml})$ (range $271.0-1121.0 \mu \mathrm{mol} /$ 1). Six patients were on dietary treatment and not yet dialysed and nine were on regular haemodialysis treatment. The mean duration of haemodialysis treatment was 4.8 months (range 0-26 months). None had received corticosteroid or immunosuppressive treatment at the time of first examination. Two patients were again analysed after a successful renal transplantation.

In five patients the hyperplasia of Brunner's glands was evident both macroscopically, appearing as multiple duodenal polyps, and histologically. ${ }^{1}$ In five patients Brunner's gland hyperplasia was mild and evident only upon histological analysis. In a further five patients no signs of Brunner's gland hyperplasia were found by either method. The groups were matched in regard to age, sex, mean concentration of serum creatinine, mean duration of dialysis treatment and distribution of non-dialysed and dialysed patients. 


\section{ENDOSCOPY}

Endoscopy was performed with an Olympus GIF-Q panendoscope. Two biopsy specimens were taken from the duodenal bulb, the gastric antrum and the corpus of each patient. Paraffin sections of formaldehyde-fixed tissues were stained with haematoxylin and eosin and alcian blue PAS. Brunner's gland hyperplasia was graded as follows: (a) severe, if multiple polyps were found in the duodenal bulb at endoscopy and if hyperplasia was evident upon histological analysis, (b) mild, if the duodenal mucosa appeared normal at endoscopy, but fibrous Brunner's gland elements with dilated ducts lined by flattened epithelium was seen histologically, and (c) no hyperplasia if both endoscopy and histological analysis were normal. The severity of gastritis was interpreted according to the criteria of Siurala $e t a l,{ }^{9}$ and the severity of duodenitis according to Whitehead et al ${ }^{10}$

\section{ACID SECRETION TESTS}

The acid secretion tests were performed by the nasogastric intubation and suction method after overnight fasting according to Baron. ${ }^{11}$ During the first hour of the test basal acid output was measured. Then $6 \mu$ g pentagastrin (Peptavlon ${ }^{\circledR}, \mathrm{ICI}$, England) per $\mathrm{kg} /$ body weight was given intramuscularly and pentagastrin-stimulated peak acid output was measured during the following hour. The peak response was calculated by adding together the two consecutive 15 minute periods with the highest secretion and multiplying the sum by 2 . The acid concentration - that is, 'free acid', was determined by titration to $\mathrm{pH} 3.5$ with an automatic titrator (Radiometer, Copenhagen, Denmark).

\section{ANALYSIS OF SERUM PEPSINOGENS}

Serum PG I concentration was determined by radioimmunoassay. In this method a lactoperoxidase sorbent is used to iodinate PG I, ${ }^{12}$ and a double antibody solid phase ${ }^{13}$ technique is applied to separate the bound and free fractions. Two $\mathrm{mCi}$ $\mathrm{Na}^{125}$ I (IMS 300, Amersham, England), $2 \mu \mathrm{l} 8.8$ $\mathrm{mmol} / 1 \mathrm{H}_{2} \mathrm{O}_{2}$ and $0.8 \mathrm{mg}$ lactoperoxidase sorbent were used to iodinate $2 \mu \mathrm{g}$ PG I (Orion Diagnostica, Helsinki, Finland) at $\mathrm{pH} 6.5$ in $0.1 \mathrm{~mol} / \mathrm{l}$ sodium acetate buffer. The RIA antiserum (Orion Diagnostica, Helsinki, Finland) was diluted $1: 35000$. Serum samples (diluted 1:20) and standards were incubated overnight at $+4^{\circ} \mathrm{C}$ before the second incubation with double antibody solid phase, which lasted four hours at $+4^{\circ} \mathrm{C}$. The serum dilution curve was parallel with the standard curve in the range from $1-100 \mu \mathrm{g} / \mathrm{l}$, using $0.04 \mathrm{~mol} / \mathrm{l}$ phosphate buffered saline, $\mathrm{pH} 7 \cdot 5$, containing $1 \%$ bovine serum albumin and $1000 \mathrm{U} / \mathrm{l}$ aprotinin
(Trasylol ${ }^{\circledR}$, Berner, Finland).

PG II determinations were carried out similarly to PG I determinations. The range of the standard curve was $0-80 \mu \mathrm{g} / \mathrm{l}$ and before the assay plasma samples were diluted with assay buffer one in five. Antiserum dilution used in the assay varied between 1:70 000 and 1:80 000. The antiserum and purified PG II for labelling and standards were the generous gift of I M Samloff.

In every series of determinations two control sera (high and low level) were included and the quality control chart was plotted. The interassay coefficients of variation calculated from these values were $8.2 \%$ (at the level of $143 \mu \mathrm{g} / \mathrm{l}$ ) and $10.7 \%$ (at the level of $71 \mu \mathrm{g} / \mathrm{l}$ ) for PG I and $7.4 \%$ (at the level of $18 \mu \mathrm{g} / \mathrm{l}$ ) and $6.7 \%$ (at the level of $12 \mu \mathrm{g} / \mathrm{l}$ ) for PG II.

The health related reference intervals with these methods were $50-150 \mu \mathrm{g} / \mathrm{l}$ for PG I and 3-18 $\mu \mathrm{g} / \mathrm{l}$ for PG II. As the reference group for PG I and II served 31 healthy subjects.

\section{STATISTICS}

The Wilcoxon's rank sum test and $\chi^{2}$ test were used in the statistical analysis. All the procedures in this study were in accordance with the ethical standards of the Helsinki Declaration of 1975.

\section{Results}

The mean serum PG II was significantly higher in patients with severe Brunner's gland hyperplasia than in the other groups $(p<0 \cdot 05)$. These patients also had lower PG I/II ratios, lower stimulated or unstimulated gastric acid output and higher $\mathrm{pH}$ of gastric resting juice. These differences were not, however, significant. Values for patients with mild hyperplasia were intermediate between the values of patients with severe and no Brunner's gland hyperplasia. In those two patients who received a well functioning renal transplant, serum PG I decreased from $157 \mu \mathrm{g} / \mathrm{l}$ to $78 \mu \mathrm{g} / \mathrm{l}(50 \%)$ and from $200 \mu \mathrm{g} / \mathrm{l}$ to $152 \mu \mathrm{g} / \mathrm{l}(24 \%)$ and serum PG II from $47 \mu \mathrm{g} / \mathrm{l}$ to 27 $\mu \mathrm{g} / \mathrm{l}(43 \%)$ and from $18 \mu \mathrm{g} / \mathrm{l}$ to $8 \mu \mathrm{g} / \mathrm{l}(56 \%)$. The mean concentrations of serum creatinine and serum PG I and II, the mean ratios of PG I/II and the mean results of the acid secretion tests in each group are summarised in Table $I$. The distribution of the serum concentrations of PG II in individual patients is shown in the Figure.

The incidence and severity of duodenitis increased with the increase in the degree of Brunner's gland hyperplasia in the present series. Among the cases of severe Brunner's gland hyperplasia, one patient had severe duodenitis, one moderate duodenitis, and the rest mild inflammation. On the other hand, among the 
Table 1 Mean concentrations of serum creatinine and serum group I and II pepsinogens, the mean ratios of the pepsinogens and the mean results of acid secretion tests in uraemic patients with severe, mild or no Brunner's gland hyperplasia (mean $\pm S E M)$

\begin{tabular}{|c|c|c|c|}
\hline Variable & $\begin{array}{l}\text { Severe hyperplasia } \\
(n=5)\end{array}$ & $\begin{array}{l}\text { Mild hyperplasia } \\
(n=5)\end{array}$ & $\begin{array}{l}\text { No hyperplasia } \\
(n=5)\end{array}$ \\
\hline Serum creatinine $+(\mu \mathrm{mol} / \mathrm{l})$ & $737 \cdot 2 \pm 103 \cdot 1$ & $736 \cdot 8 \pm 95 \cdot 6$ & $726 \cdot 6 \pm 135 \cdot 2$ \\
\hline Serum group I pepsinogens $(\mu \mathrm{g} / \mathrm{l})$ & $224 \cdot 4 \pm 40 \cdot 5$ & $566 \cdot 8 \pm 387 \cdot 9$ & $232 \cdot 0 \pm 42 \cdot 9$ \\
\hline Serum group II $\ddagger$ pepsinogens $(\mu \mathrm{g} / \mathrm{l})$ & $43 \cdot 0 \pm 10 \cdot 4$ & $25 \cdot 0 \pm 6 \cdot 9$ & $18 \cdot 2 \pm 2 \cdot 4^{*}$ \\
\hline Pepsinogen I/II ratio & $6 \cdot 5 \pm 2 \cdot 0$ & $19 \cdot 1 \pm 7 \cdot 7$ & $14 \cdot 5 \pm 3 \cdot 7$ \\
\hline Basal acid output (mEq/h) & $0 \cdot 9 \pm 0 \cdot 6$ & $0 \cdot 7 \pm 0 \cdot 5$ & $2 \cdot 5 \pm 1 \cdot 6$ \\
\hline Pentagastrin stimulated peak acid output $(\mathrm{mEq} / \mathrm{h})$ & $8 \cdot 6 \pm 5 \cdot 2$ & $15 \cdot 1 \pm 2 \cdot 4$ & $25 \cdot 4 \pm 9 \cdot 4$ \\
\hline $\mathrm{pH}$ of resting juice & $6 \cdot 9 \pm 1 \cdot 3$ & $4 \cdot 8 \pm 1 \cdot 1$ & $3 \cdot 0 \pm 0 \cdot 4$ \\
\hline
\end{tabular}

* $\mathrm{p}$ value between severe Brunner-hyperplasia and others $<0 \cdot 05$.

$\dagger$ conversion factor: $0.01131 \mathrm{mg} / 100 \mathrm{ml}$.

$\ddagger$ conversion factor: $1 \times 10^{-4} \mathrm{mg} / 100 \mathrm{ml}$.

patients with no sign of Brunner's gland hyperplasia two had normal duodenal histology and the remainder mild duodenitis. There was no significant difference in the severity of gastritis (Table 2), nor in the acid secretion capacity between the groups.

\section{Discussion}

Brunner's glands are mainly located in the first part of the duodenum. A severe hyperplasia of these glands is often encountered as an accidental finding at endoscopy and is a harmless asymptomatic clinical disorder. In its extreme form, however, it may lead to duodenal obstruction as $\mathrm{we}^{1}$ and others ${ }^{14}$ have reported. Thus a clinician dealing with a patient with upper gastrointestinal complaints should be aware of the existence of this disorder as one, albeit rare reason for these complaints,

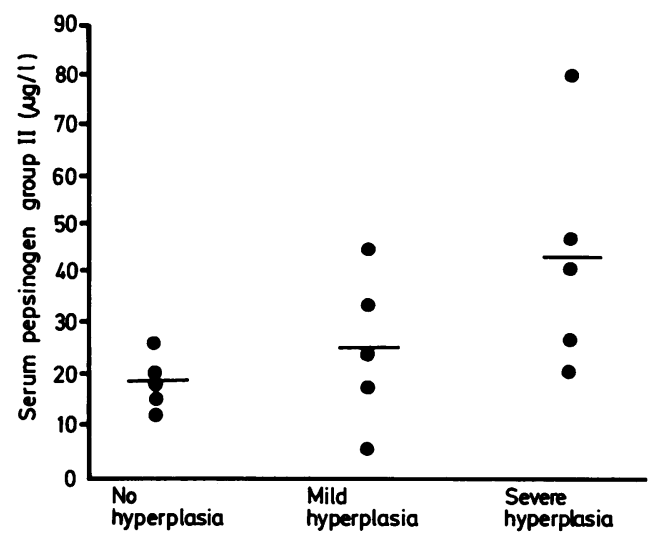

Figure Serum concentration of group II pepsinogens in individual patients with severe, mild and no Brunner's gland hyperplasia $(-=$ mean value $)$. especially where the patient suffers from chronic renal failure. The diagnosis of Brunner's gland hyperplasia is primarily based on histological analysis of a specimen from the duodenal wall, though endoscopic and radiologic findings are very suggestive. In the present series Brunner's gland hyperplasia increased in its severity with the increase in duodenitis, both of which seem to be increasingly encountered in uraemia. ${ }^{141516}$

PG II originates in the corpus and the antrum of the human stomach and also in the Brunner's glands of the duodenum, unlike PG I which originates only in the corpus. This has been histochemically verified by Samloff. ${ }^{71}$ As has been noted in the literature, the serum PG I concentration correlates well with the functional capacity of the corpus. ${ }^{18}$ Analogously one could expect the serum PG II concentration to be increased in the case of hyperplasia of Brunner's glands, as was indeed found in the present study.

The patients with severe Brunner's glands hyperplasia tended to have more alkaline gastric resting juice as well as lower gastric acid secretion capacity than the other patients in the series. These minor differences in the acid secretion capacity between the groups may have been because of gastritic changes, although these groups did not differ statistically in respect to gastric histology. As to the cell mass producing PG II these groups differed in the size of Brunner's glands. Thus, it seems improbable that the difference in serum PG II between the groups would be due to gastritic changes, ${ }^{19}$ but rather to the difference in the size of Brunner's glands. Though the contribution of these glands to serum PG II concentration normally may be very small, this may not be so in severe Brunner's gland hyperplasia.

The serum PG II concentration of patients without Brunner's gland hyperplasia fell within the reference interval, despite the similar functional 
Table 2 Summary of endoscopical findings with histological verification within the gastroduodenal area in uraemic patients with severe, mild and no Brunner's gland hyperplasia

\begin{tabular}{|c|c|c|c|}
\hline Variable & $\begin{array}{l}\text { Severe hyperplasia } \\
(n=5)\end{array}$ & $\begin{array}{l}\text { Mild hyperplasia } \\
(n=5)\end{array}$ & $\begin{array}{l}\text { No hyperplasia } \\
(n=5)\end{array}$ \\
\hline \multicolumn{4}{|l|}{ Duodenum } \\
\hline normal & - & 1 & 2 \\
\hline mild duodenitis & 3 & 4 & 3 \\
\hline moderate duodenitis & 1 & - & - \\
\hline severe duodenitis & 1 & - & - \\
\hline multiple polyps & 5 & - & - \\
\hline \multicolumn{4}{|l|}{ Stomach } \\
\hline \multicolumn{4}{|l|}{ Antrum } \\
\hline normal & 1 & 1 & 1 \\
\hline superficial gastritis & 4 & 4 & 4 \\
\hline mild atrophic gastritis & - & - & - \\
\hline moderate atrophic gastritis & - & - & - \\
\hline severe atrophic gastritis & - & - & - \\
\hline \multicolumn{4}{|l|}{ Corpus } \\
\hline normal & 1 & - & 2 \\
\hline superficial gastritis & 2 & 1 & 2 \\
\hline mild atrophic gastritis & 2 & 3 & 1 \\
\hline moderate atrophic gastritis & - & 1 & - \\
\hline severe atrophic gastritis & - & - & - \\
\hline
\end{tabular}

deterioration of their kidneys to the other patients in the series. On the other hand, normalisation of the renal function through surgery in two patients caused a reduction in the serum PG II concentrations, suggesting that the kidneys are in fact involved in the elimination of serum PG II. Views on this last point vary, ${ }^{202}$ and clarification must await further studies. Furthermore, the fate of the Brunner's gland hyperplasia after transplantation is still unclear. The favourable effect of transplantation on the nodular form of duodenitis has been reported by Zukerman et al. ${ }^{16}$

This study has been financially supported by the Finska Läkaresällskapet and the Sigrid Jusélius Foundation.

\section{References}

1 Paimela H, Tallgren LG, Stenman S, v Numers H, Scheinin TM. Multiple duodenal polyps in uraemia: a little known clinical entity. Gut 1984; 25: 259-63.

2 Muolo A, Chidini O, Ancona G, et al. Gastroduodenal mucosal changes, gastric acid secretion and gastrin levels following successful kidney transplantation. Transplant Proc 1979; 11: 1277-9.

3 Franzin G, Musola R, Mencarelli R. Morphological changes of the gastroduodenal mucosa in regular dialysis uraemic patients. Histopathology 1982; 6: 429-37.

4 Feyrter F. Über wucherungen der brunnerschen drüsen. Virchows Arch Pathol Anat 1934; 293: 509-26.

5 Leeson TS, Leeson CR. The fine structure of Brunner's glands in man. J Anat 1968; 103: 263-76.

6 Cooke AR, Grossman MI. Studies on the secretion and motility of Brunner's gland pouches. Gastroenterology 1966; 51: 506-14.

7 Samloff IM, Liebman WM. Cellular localization of the group II pepsinogens in human stomach and duodenum by immunofluorescence. Gastroenterology 1973; 65: $36-42$.

8 Samloff IM. Pepsinogens, pepsins, and pepsin inhibitors. Gastroenterology 1971; 60: 586-604.

9 Siurala M, Isokoski M, Varis K, Kekki M. Prevalence of gastritis in a rural population. Scand J Gastroenterol 1968; 3: 211-23.

10 Whitehead R, Roca M, Meikle DD, Skinner J, Truelove SC. The histological classification of duodenitis in fibreoptic biopsy specimens. Digestion 1975; 13: 129-36.

11 Baron JH. The clinical application of gastric secretion measurements. Clin Gastroenterol 1973; 2: 293-314.

12 Karonen S-L, Mörsky P, Siren M, Seuderling U. An enzymatic solid-phase method for trace iodination of proteins and peptides with 125 iodine. Anal Biochem 1975; 67: 1-10.

13 Den Hollander FC, Schuurs AHWM. In: Kirkham KE, Hunter WM, eds. Radioimmunoassay methods. Edinburgh: Livingstone, 1971.

14 Kaplan EL, Dyson WL, Fitts WT. Hyperplasia of Brunner's glands of the duodenum. Surg Gynecol Obstet 1968; 126: 371-5.

15 Margolis DM, Saylor JL, Geisse G, DeSchryverKecskemeti K, Harter HR, Zuckerman GR. Upper gastrointestinal disease in chronic renal failure. Arch Intern Med 1978; 138: 1214-7. 
16 Zukerman GR, Mills DBA, Koehler RE, Siegel A, Harter HR, DeSchryver-Kecskemeti K. Nodular duodenitis. Dig Dis Sci 1983; 28: 1018-24.

17 Samloff IM. Cellular localization of group I pepsinogens in human gastric mucosa by immunofluorescence. Gastroenterology 1971; 61: 185-8.

18 Samloff IM, Secrist DM, Passaro E Jr. A study of the relationships between serum group I pepsinogen levels and gastric acid secretion. Gastroenterology 1975; 69: 1196-200.

19 Samloff IM, Varis K, Ihamäki T, Siurala M, Rotter JI.
Relationships among serum pepsinogen I, serum pepsinogen II, and gastric mucosal histology. Gastroenterology 1982; 83: 204-9.

20 Samloff IM, Townes PL. Electrophoretic heterogeneity and relationships of pepsinogens in human urine, serum, and gastric mucosa. Gastroenterology 1970; 58: 462-9.

21 Ichinose M, Miki K, Furihata C, et al. Radioimmunoassay of serum group I and group II pepsinogens in normal controls and patients with various disorders. Clin Chim Acta 1982; 126: 183-91. 